\title{
Leptospirosis in South Africa
}

\author{
Authors: \\ Adrienne Saif ${ }^{1,2}$ \\ John Frean ${ }^{1,2}$ \\ Jenny Rossouw \\ Anastasia N. Trataris ${ }^{1,2}$ \\ Affiliations: \\ ${ }^{1}$ University of the \\ Witwatersrand, South Africa \\ ${ }^{2}$ Special Bacterial Pathogens \\ Reference Unit, National \\ Institute for Communicable \\ Diseases, National Health \\ Laboratory Services, \\ South Africa \\ Correspondence to: \\ Adrienne Saif \\ Email: \\ adriennes@nicd.ac.za \\ Postal address: \\ Private Bag X4, Sandringham \\ 2131, South Africa \\ How to cite this poster: \\ Saif, A., Frean, J., Rossouw, \\ J. \& Trataris, A.N., 2012, \\ 'Leptospirosis in South \\ Africa', Onderstepoort \\ Journal of Veterinary \\ Research 79(2), Art. \#478, \\ 1 page. http://dx.doi. \\ org/10.4102/ojvr.v79i2.478 \\ Note: \\ Proceedings of the \\ Conference of the Southern \\ African Centre for Infectious \\ Disease Surveillance 'One \\ Health' held at the National \\ Institute for Communicable \\ Diseases, Johannesburg, July \\ 2011.
}

\section{(C) 2012. The Authors.} Licensee: AOSIS OpenJournals. This work is licensed under the Creative Commons Attribution License.
Leptospirosis is a common zoonosis worldwide. It has a ubiquitous distribution and causes a wide spectrum of disease. Leptospirosis therefore has a broad reservoir host range, and many infected species of animals excrete leptospires in their urine, which leads to contamination of soil and water. Typical descriptions of the disease include a biphasic (anicteric form) and fulminant disease in the icterohaemorrhagic form. Only a few local case reports of human leptospirosis have been published, the most recent one being in 1974 .

A rodent-related zoonosis study (RatZooMan) was conducted from 2003 until 2006 in three provinces (Limpopo, KwaZulu-Natal and the Eastern Cape). Of the people sampled in Cato Crest (Durban, KwaZulu-Natal Province), 43/217 (19.8\%) were seropositive for leptospirosis. Of the clinical samples sent to the Special Bacterial Pathogens Reference Unit from all over the country for testing in 2009, 16/176 (9\%) were IgM positive; in 2010 and January 2011 to May 2011, 14/215 $(6.5 \%)$ and $12 / 96(12.5 \%)$, respectively, were $\operatorname{IgM}$ positive.

The apparent incidence of leptospirosis in the South African population is moderately high based on the detected positives in suspected cases; it is thought that the circulating infection rate may be even higher when looking at the RatZooMan results. This may be due to underreporting and undiagnosed cases. Communities in informal settlements in urban areas are especially at risk as infected rodent populations are a continuous source of transmission. 